\title{
Genetic testing utilization for patients with neurologic disease and the limitations of claims data
}

Samuel J. Mackenzie, MD, PhD, Chun Chieh Lin, PhD, MBA, Peter K. Todd, MD, PhD, James F. Burke, MD, MS, and Brian C. Callaghan, MD, MS

Neurol Genet 2020;6:e405. doi:10.1212/NXG.0000000000000405

\section{Abstract}

\section{Objective}

To determine the utilization of genetic testing in patients seen by a neurologist within a large private insurance population.

\section{Methods}

Using the Optum health care claims database, we identified a cross-sectional cohort of patients who had been evaluated by a neurologist no more than 30 days before initial genetic testing. Within this group, we then categorized genetic testing between 2014 and 2016 on the basis of the Current Procedural Terminology (CPT) codes related to molecular and genetic testing. We also evaluated the International Classification of Disease Version 9 Clinical Code Classifications (ICD-9 CCS) associated with testing.

\section{Results}

From 2014 to 2016, a total of 45,014 claims were placed for 29,951 patients who had been evaluated by a neurologist within the preceding 30 days. Of these, 29,926 (66.5\%) were associated with codes that were too nonspecific to infer what test was actually performed. Among those claims where the test was clearly identifiable, 7,307 (16.2\%) were likely obtained for purposes of neurologic diagnosis, whereas the remainder (17.2\%) was obtained for nonneurological purposes. An additional 3,793 claims (8.4\%) wherein the test ordered could not be clearly identified were associated with a neurology-related ICD-9 CCS.

\section{Conclusions}

Accurate assessment of genetic testing utilization using claims data is not possible given the high prevalence of nonspecific codes. Reducing the ambiguity surrounding the CPT codes and the actual testing performed will become even more important as more genetic tests become available.
Correspondence

Dr. Callaghan

bcallagh@med.umich.edu

From the Division of Pediatric Neurology (S.J.M.), Department of Pediatrics, University of Michigan; Department of Neurology (C.C.L, P.K.T., J.F.B, B.C.C.), University of Michigan; Department of Veterans Affairs Ann Arbor Healthcare System (P.K.T., J.F.B, B.C.C.); and the Institute for Healthcare Policy and Innovation (J.F.B, B.C.C.), University of Michigan, Ann Arbor, MI. 


\section{Glossary}

CPT $=$ Current Procedural Terminology; ICD-9 CCS = International Classification of Disease Version 9 Clinical Code Classification.

Clinical genetic testing is an increasingly common component of modern-day neurologic practice, with a rapidly growing set of tools available for ascertaining the potential causes of disease. Over the past 2 decades, next-generation sequencing has made it possible to probe multiple gene targets on an exponentially larger scale at relatively low processing costs. ${ }^{1}$ However, this less-targeted approach may identify incidental findings and carry additional expenses associated with data interpretation and counseling. ${ }^{2,3}$

As more tests come to the market, ordering physicians may struggle with what test or sequence of tests to pursue to minimize the cost, time to diagnosis, and incidental findings. Although most neurologists surveyed in a 2014 study selfreported ordering genetic testing on a regular basis, most also reported deficiencies in their knowledge of genetics and ability to interpret tests. ${ }^{4}$ Ascertaining what tests neurologists are commonly ordering in real-world practice would provide a foundation for addressing these problems. Unfortunately, little is known about the utilization of genetic testing on a population-wide scale.

In this study, we aimed to determine the use of genetic testing among patients who were evaluated by an outpatient neurologist from 2014 to 2016 through targeted analysis of a large set of private insurance claims data.

\section{Methods}

\section{Standard protocol approvals, registrations, and patient consent}

This study was approved by the University of Michigan Institutional Review Board.

\section{Data collection and analysis}

The Optum health care claims database comprises deidentified medical claims data for several million privately insured individuals across the country. We identified a crosssectional cohort of patients who had been evaluated by a neurologist between 2014 and 2016. We then extracted claims data associated with molecular and genetic testing Current Procedural Terminology (CPT) codes submitted within 30 days of their neurology visit. We categorized the tests by diagnostic intent as "neurologic or likely neurologic;" "non-neurologic," or "unknown" on the basis of code description and author consensus (table e-1, links.lww.com/ $\mathrm{NXG/A232).} \mathrm{All} \mathrm{codes} \mathrm{related} \mathrm{to} \mathrm{a} \mathrm{molecular} \mathrm{diagnosis} \mathrm{of}$ cancer, including those potentially related to neuro-oncological diagnoses, were categorized as "non-neurological." All codes related to genetic testing for an underlying coagulopathy that may predispose a patient to cerebrovascular disease were categorized as "neurologic."

To better evaluate whether testing was ordered as part of a neurologic evaluation, we also evaluated codes associated with neurology-related International Classification of Disease Version 9 clinical code classifications (ICD-9 CCS).

Data queries were performed using SAS 9.4 for Windows (Cary, NC).

\section{Data availability}

All data relevant to this study are contained within the article and supplemental materials.

\section{Results}

From 2014 to 2016, a total of 45,014 claims were placed for initial molecular and genetic testing in 29,951 patients evaluated by a neurologist within the preceding 30 days. The mean patient age was 45 years (SD 20.2 years), and 4,114 patients (10.5\%) were younger than the age of 18 years at the time of claims submission. Most patients $(25,162 ; 84 \%)$ had only a single claim associated with testing. Among the remaining patients with more than 1 claim submitted as part of their initial genetic testing, an average of $4.1 \pm 2.8$ (mean \pm SD) claims were placed (range 2-28).

The most common CPT code submitted across all patients was 89,240 for "Unlisted miscellaneous pathology test" $(19,564 ; 43.5 \%$; figure). The diagnostic test performed could not be ascertained for most codes submitted $(29,926$; $66.5 \%$; figure). On the basis of testing claims alone, we estimated that approximately 7,307 (16.2\%; figure) were sent for the purposes of neurologic diagnosis, most commonly, to help determine the presence of an underlying coagulopathy (CPT 81241, factor V Leiden: 2,115 claims [4.7\%]; CPT 81291, MTHFR mutation: 1,961 claims [4.4\%]; CPT 81240, Prothrombin gene mutation: 1,773 claims [3.9\%]; figure).

Only 4,823 claims (10.7\%) were associated with a neurology-related ICD-9 CCS. These claims were categorized as follows: 652 neurologic or likely neurologic, 379 nonneurological, and 3,793 unknown. "Epilepsy; convulsions" (745; 1.7\%), "Other nervous system symptoms and disorders" (593; 1.3\%), "Disorders of the peripheral nervous system" (592; 1.3\%), and "Headache; including migraine" $(591 ; 1.3 \%)$, were the most commonly associated classifications. The CPT code 89,240 for the "Unlisted 
Figure Categorization of molecular and genetic testing CPT codes in patients evaluated by a neurologist within 30 days of testing, 2014-2016

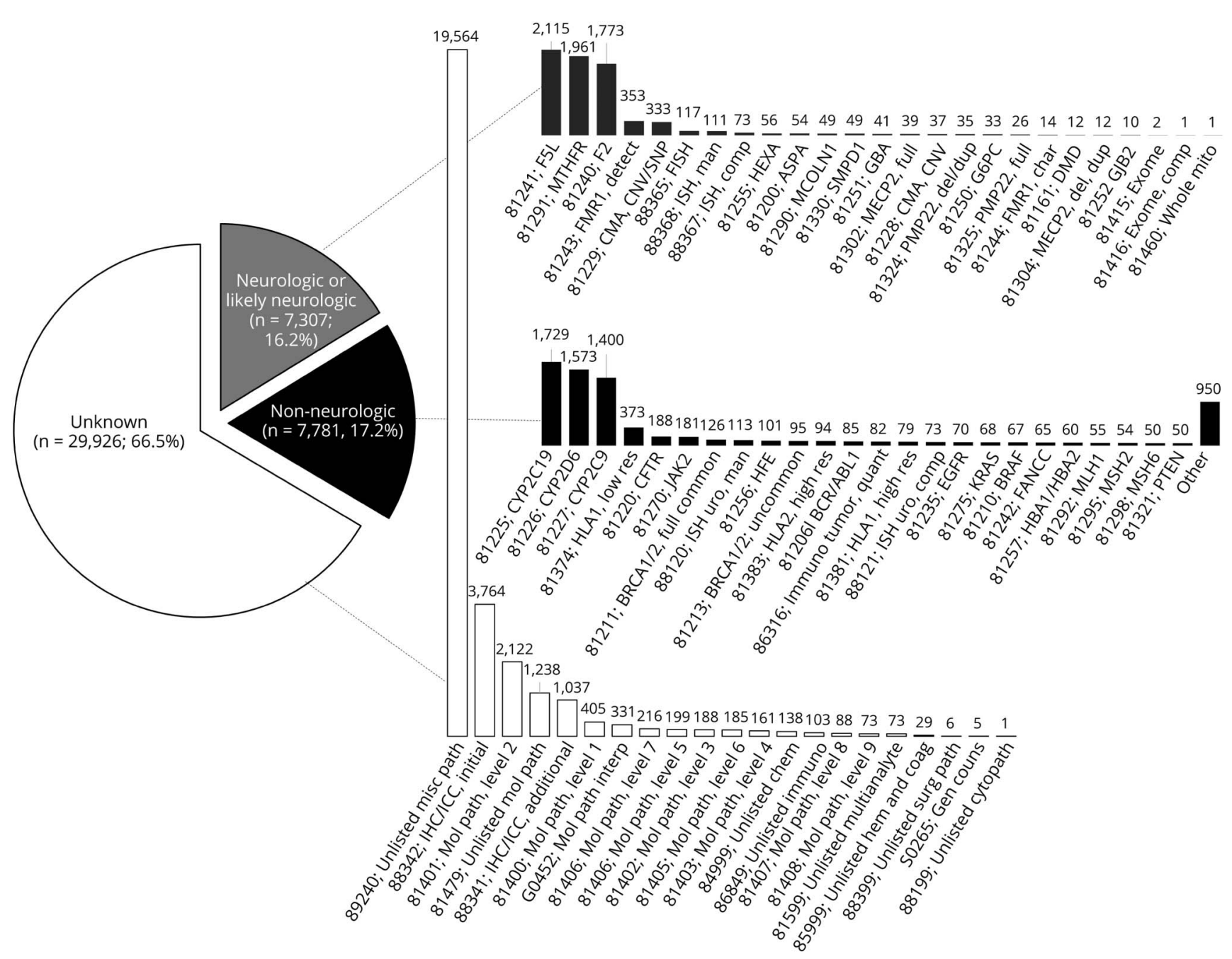

Most codes were categorized as "unknown" on the basis of unknown diagnostic intent and ambiguous test represented ( $\mathrm{N}=29,926 ; 66.5 \%)$. Among codes categorized as "neurologic or likely neurologic" ( $N=7,307,16.2 \%)$, most testing was obtained for diagnosis of underlying coagulopathy. Unabbreviated descriptions of tests are provided in table e-1, links.Iww.com/NXG/A232. CPT = Current Procedural Terminology.

miscellaneous pathology test" was the most common code associated with each neurology-related ICD-9 CCS.

\section{Discussion}

Our objective was to determine how genetic testing is being used in patients with neurologic disease on a populationwide scale, although we found that it is extremely difficult to evaluate the utilization of genetic testing in a modern claims database because of the nonspecificity of codes. In our cohort of privately insured neurology patients who underwent genetic testing from 2014 to 2016, most testing was not identifiable on the basis of CPT coding because two-thirds of claims used nonspecific codes. In addition, tracking the use of many newer single gene tests, gene panels, and exome/ genome sequencing was not possible. A minority of patients analyzed had a neurology-related ICD-9 CCS associated with their claims, and this association did not reduce the ambiguity surrounding what test was ordered.

According to the NIH's Genetic Testing Registry, at the time of this writing, there are over 60,000 genetic tests available on the market compared with just 1,038 tests in $2012 .^{5}$ As the volume of molecular pathology testing has increased, the American Medical Association's CPT Molecular Pathology Coding Workgroup transitioned from a methodology-based "stacking code" system to new system of "tiered" codes, wherein analytespecific high-volume tests are given a tier 1 designation and tests for less common diseases are categorized as tier 2. ${ }^{6,7}$ Tier 2 codes, sometimes referred to as "umbrella" codes, given that multiple diseases may be tested for under the same code, now reflect only the laboratory methods used for running the test. ${ }^{8}$

Unfortunately, it was not possible to determine diagnostic intent through analysis of tier 2 codes, which represented 3,637 
(8.2\%) of tests in our study. This finding is consistent with previously reported use of tier 2 codes in a population of Medicare patients, ${ }^{9}$ suggesting that the root cause of the ambiguity lies in the codes themselves and not the databases housing the resulting claims. Of interest, although tier 1 codes were initially intended to represent tests completed at high volume, claims submitted for some tier 1 conditions such as Fragile X (367; 0.8\%), Duchenne muscular dystrophy (12; $<0.1 \%$ ), and Charcot-Marie-Tooth (PMP22; 61; 0.1\%) were observed with relatively low frequency. Tier 1 codes pertaining to a possible underlying coagulopathy diagnosis predisposing to cerebrovascular disease were used more commonly.

We hypothesize that several tests with specific corresponding codes may have been coded under nonspecific designations instead. As an example, whole exome sequencing, a technique that has been demonstrated to have a high diagnostic yield in a number of clinical contexts within neurology, including ataxia, autism, and intellectual disability, ${ }^{10}$ was identifiable through its specific codes ( 81215 and 81416 ) in only 3 cases. In addition, a significant amount of other (nongenetic) diagnostic testing was likely captured through nonspecific codes such as 89240 (unlisted miscellaneous pathology test).

Accurate population-based utilization data may help identify disparities in genetic testing among certain patient populations, determine total and out-of-pocket costs associated with genetic testing, elucidate how often certain molecular targets may be being redundantly probed by way of serial testing, and identify ways to optimize time to diagnosis in a cost-effective manner. Our study suggests, however, that traditional claims-based methods have limited application to genetic testing at present, given the nonspecificity of unlisted and tier 2 molecular pathology codes. Given the speed with which new genetic tests come into and out of the market, this is a problem that warrants careful consideration going forward. Potential solutions will likely require input from multiple stakeholders, including health systems, payers, and commercial laboratories.

\section{Study funding}

No targeted funding reported.

\section{Dislosure}

Disclosures available: Neurology.org/NG.

\section{Publication history}

Received by Neurology: Genetics September 23, 2019. Accepted in final form January 9, 2020.

\section{Appendix Authors}

\begin{tabular}{|c|c|c|c|}
\hline Name & Location & Role & Contribution \\
\hline $\begin{array}{l}\text { Samuel J. } \\
\text { Mackenzie, } \\
\text { MD, PhD }\end{array}$ & $\begin{array}{l}\text { University of } \\
\text { Michigan, Ann } \\
\text { Arbor, MI }\end{array}$ & Author & $\begin{array}{l}\text { Designed and directed the } \\
\text { research project; analyzed } \\
\text { the data; participated in the } \\
\text { data interpretation; created } \\
\text { figure; drafted, reviewed, } \\
\text { and approved the final } \\
\text { manuscript }\end{array}$ \\
\hline $\begin{array}{l}\text { Chun Chieh } \\
\text { Lin, PhD, } \\
\text { MBA }\end{array}$ & $\begin{array}{l}\text { University of } \\
\text { Michigan, Ann } \\
\text { Arbor, MI }\end{array}$ & Author & $\begin{array}{l}\text { Collected and analyzed } \\
\text { data; participated in the } \\
\text { data interpretation } \\
\text { reviewed and } \\
\text { approved the } \\
\text { final manuscript }\end{array}$ \\
\hline $\begin{array}{l}\text { Peter K. } \\
\text { Todd, MD, } \\
\text { PhD }\end{array}$ & $\begin{array}{l}\text { University of } \\
\text { Michigan, Ann } \\
\text { Arbor, MI }\end{array}$ & Author & $\begin{array}{l}\text { Participated in the data } \\
\text { interpretation; reviewed } \\
\text { and approved the final } \\
\text { manuscript }\end{array}$ \\
\hline $\begin{array}{l}\text { James F. } \\
\text { Burke, MD, } \\
\text { MS }\end{array}$ & $\begin{array}{l}\text { University of } \\
\text { Michigan, Ann } \\
\text { Arbor, MI }\end{array}$ & Author & $\begin{array}{l}\text { Designed and directed the } \\
\text { research project; } \\
\text { participated in the data } \\
\text { interpretation; reviewed } \\
\text { and approved the final } \\
\text { manuscript }\end{array}$ \\
\hline $\begin{array}{l}\text { Brian C. } \\
\text { Callaghan, } \\
\text { MD, MS }\end{array}$ & $\begin{array}{l}\text { University of } \\
\text { Michigan, Ann } \\
\text { Arbor, MI }\end{array}$ & Author & $\begin{array}{l}\text { Designed and directed the } \\
\text { research project; } \\
\text { participated in the data } \\
\text { interpretation; reviewed } \\
\text { and approved the final } \\
\text { manuscript }\end{array}$ \\
\hline
\end{tabular}

\section{References}

1. Klein CJ, Foroud T. Neurology individualized medicine: when to use next-generation sequencing panels. Mayo Clin Proc 2017;92:292-305.

2. Riley JD, Procop GW, Kottke-Marchat K, Wyllie R, Lacbawan FL. Improving molecular genetic test utilization through order restriction, test review, and guidance. J Mol Diagn 2015;17:225-229.

3. Biesecker LG, Green RC. Diagnostic clinical genome and exome sequencing. N Engl J Med 2014:2418-2425.

4. Salm M, Abbate K, Appelbaum P, et al. Use of genetic tests among neurologists and psychiatrists: knowledge, attitudes, behaviors, and needs for training. J Genet Couns 2014;23:156-163.

5. National Institutes of Health Genetic Testing Registry [online]. Available at: ncbi. nlm.nih.gov/gtr/. Accessed July 25, 2019.

6. Hsiao SJ, Mansukhani MM, Carter MC, Sireci AN. The history and impact of molecular coding changes on coverage and reimbursement of molecular diagnostic tests: transition from stacking codes to the current molecular code set including genomic sequencing procedures. J Mol Diagn 2018;20: 177-183.

7. Klein $\mathrm{RD}$. Reimbursement in molecular pathology: bringing genomic medicine to patients. Clin Chem 2015;61:136-138.

8. CPT molecular pathology tier 2 codes [online]. Available at: ama-assn.org/sites/amaassn.org/files/corp/media-browser/public/physicians/cpt/cpt-molecular-pathology-tier-2-codes.pdf. Accessed February 22, 2019.

9. Lynch JA, Berse B, Dotson WD, Khoury J, Coomer N, Kautter J. Utilization of genetic tests: analysis of gene-specific billing in Medicare claims data. Genet Med 2017;19: 890-899.

10. Fogel BL, Satya-Murti S, Cohen BH. Clinical exome sequencing in neurologic disease. Neurol Clin Pract 2016;6:164-176. 


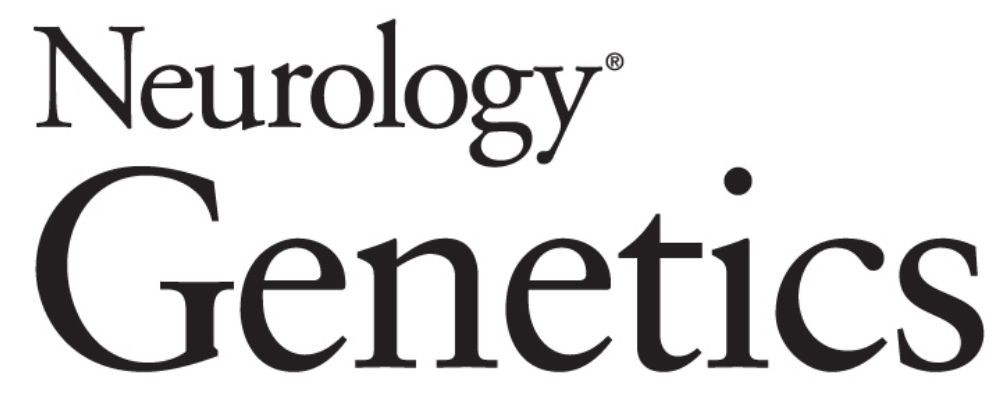

\section{Genetic testing utilization for patients with neurologic disease and the limitations of claims data \\ Samuel J. Mackenzie, Chun Chieh Lin, Peter K. Todd, et al. \\ Neurol Genet 2020;6; \\ DOI 10.1212/NXG.0000000000000405}

This information is current as of February 26, 2020

\section{Updated Information \& Services}

References

Subspecialty Collections

Permissions \& Licensing

Reprints including high resolution figures, can be found at: http://ng.neurology.org/content/6/2/e405.full.html

This article cites 7 articles, 2 of which you can access for free at: http://ng.neurology.org/content/6/2/e405.full.html\#\#ref-list-1

This article, along with others on similar topics, appears in the following collection(s):

All Genetics

http://ng.neurology.org//cgi/collection/all_genetics

Coding

http://ng.neurology.org//cgi/collection/coding

Diagnostic test assessment

http://ng.neurology.org//cgi/collection/diagnostic_test_assessment Health care reform

http://ng.neurology.org//cgi/collection/health_care_reform

Information about reproducing this article in parts (figures,tables) or in its entirety can be found online at:

http://ng.neurology.org/misc/about.xhtml\#permissions

Information about ordering reprints can be found online: http://ng.neurology.org/misc/addir.xhtml\#reprintsus

Neurol Genet is an official journal of the American Academy of Neurology. Published since April 2015, it is an open-access, online-only, continuous publication journal. Copyright Copyright $\odot 2020$ The Author(s). Published by Wolters Kluwer Health, Inc. on behalf of the American Academy of Neurology.. All rights reserved. Online ISSN: 2376-7839.

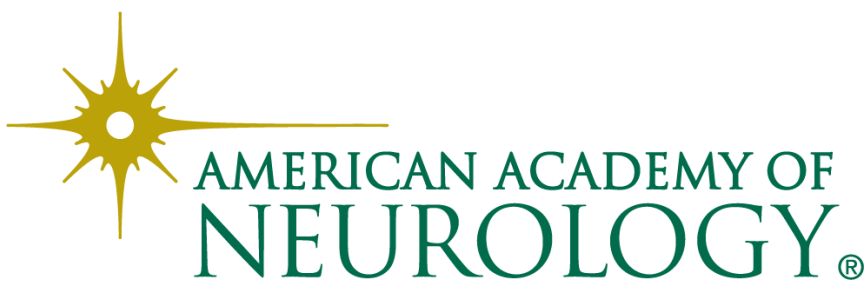

